\title{
59. DATA REPORT: ELECTRON MICROPROBE ANALYSES OF CRETACEOUS LIMESTONES FROM MIT GUYOT ${ }^{1}$
}

\author{
Robert J. van Waasbergen ${ }^{2}$ and Janet A. Haggerty ${ }^{2}$
}

\section{INTRODUCTION}

We analyzed samples from Site 878, stratigraphic Unit V (Shipboard Scientific Party, 1993), which comprised part of the lower carbonate platform of the section drilled at MIT Guyot. This work is part of an ongoing project to relate some of the surface features of the guyot to the diagenetic history of the limestone. Of particular interest is whether the observed irregular surface topography (Shipboard Scientific Party, 1993; van Waasbergen and Winterer, 1993) can be attributed to removal of soluble deposits, such as evaporites, from the subsurface.

\section{METHODS}

Polished thin sections of available sample material were made and analyzed with blue-violet fluorescence microscopy to reveal details of cement stratigraphy and other microstructures. Under blue-violet light, dolomite rhombs typically remained darker (nonfluorescent) than the surrounding calcite matrix. Variable fluorescence in cements, related to slight variations in mineralogy, trace-element chemistry of the crystals, or the abundance of fluid or solid inclusions (van Gijzel, 1979), allows the observation of the detailed growth history of individual cement generations.

Electron microprobe analysis was used to determine variations in the chemical composition of the dolomite rhombs and calcite cements. Polished thin sections were coated with silver following the method of Smith (1986). Microprobe analysis of carbonates coated with silver differs from analysis of carbonates with conventional carbon for several reasons (Smith, 1986; Daniel and Haggerty, 1988; Haggerty and Smith, 1988).

1. During electron bombardment, the silver coating inhibits thermal decomposition of carbonates better than carbon coating.

2. This enhanced stability of the carbonate mineral during electron bombardment permits the use of higher sample currents, a focused beam, and longer counting times.

3. A more focused beam on silver-coated carbonates than the diffuse beam (typically $250 \mu \mathrm{m}$ ) used on carbon-coated carbonates enhances the spatial resolution.

4. The longer counting times lowers the detection limits for trace elements in carbonate rocks.

A Cameca 3-spectrometer electron microprobe was used, with a focused beam of 4 to $6 \mu \mathrm{m}$ in diameter. We used an accelerating potential of $20 \mathrm{kV}$, and a sample current of $20 \mathrm{nA}$ (dolomite) and 12 $\mathrm{nA}$ (calcite). Counting times on peak and background for each analysis for calcite were $60 \mathrm{~s}$ for $\mathrm{Ca}$ and $\mathrm{Mg}$ and $360 \mathrm{~s}$ for $\mathrm{Fe}, \mathrm{Mn}, \mathrm{Sr}, \mathrm{Na}$, and $\mathrm{S}$. For analyses on dolomite, counting times were $10 \mathrm{~s}$ for $\mathrm{Ca}$ and $\mathrm{Mg}$ and $300 \mathrm{~s}$ for $\mathrm{Fe}, \mathrm{Mn}, \mathrm{Sr}, \mathrm{Na}$, and $\mathrm{S}$.

\footnotetext{
'Haggerty, J.A., Premoli Silva, I., Rack, F., and McNutt, M.K. (Eds.), 1995. Proc. ODP, Sci, Results, 144: College Station, TX (Ocean Drilling Program).

${ }^{2}$ Department of Geosciences, University of Tulsa, Tulsa, OK 74104, U.S.A.
}

$\mathrm{K}_{\alpha}$-peaks were used for all elements analyzed, with the exception of $\mathrm{Sr}$. Sr-LM $\varsigma_{\alpha} \alpha$ was analyzed using a thallium acid phthalate (TAP) crystal rather than the conventional pentaerythritol (PET) crystal. The $\mathrm{Sr}-\mathrm{L}_{\alpha}$ peak on a TAP crystal occurs near the lower limit of the wavelength spectrometer, which provides maximum intensity of X-rays and lowest detection limits. The $\mathrm{Sr}-\mathrm{L}_{\alpha}$ peak on the PET crystal occurs on the upper limit of the wavelength spectrometer, which causes the intensity of the X-rays to be extremely attenuated.

Detection limits for each of the elements were calculated using the equation

$$
L=X \times \frac{3 \sqrt{C}}{S},
$$

where $X=$ weight fraction of the element in the standard, $C=$ background counts measured on the unknown, and $S=$ peak counts of the element in the standard, all corrected for the counting time. Detection limits for each of the elements in calcite were as follows: $\mathrm{Ca}=180$ ppm, $\mathrm{Mg}=110 \mathrm{ppm}, \mathrm{Fe}=110 \mathrm{ppm}, \mathrm{Mn}=100 \mathrm{ppm}, \mathrm{Na}=60 \mathrm{ppm}$, $\mathrm{Sr}=93 \mathrm{ppm}$, and $\mathrm{S}=128 \mathrm{ppm}$. Detection limits in dolomite were as follows: $\mathrm{Ca}=290 \mathrm{ppm}, \mathrm{Mg}=225 \mathrm{ppm}, \mathrm{Fe}=86 \mathrm{ppm}, \mathrm{Mn}=81 \mathrm{ppm}$, $\mathrm{Na}=55 \mathrm{ppm}, \mathrm{Sr}=92 \mathrm{ppm}$, and $\mathrm{S}=86 \mathrm{ppm}$.

Five areas were microprobed from four separate thin sections.

\section{RESULTS}

\section{Sample 144-878A-75R-1, 32-37 cm (693.8 mbsf)}

This sample consists of a porous wackestone containing small skeletal fragments of foraminifers, thin-shelled gastropods, and echinoderms in a dense micrite matrix. Moldic porosity is common, with pores frequently filled with anhedral equant calcite cement. Several large stylolite structures cross this interval. These form up to 0.5 mm-thick horizons commonly very rich in fibrous siliceous minerals such as clay or mica. Dolomite occurs in this sample as massive, unzoned euhedral rhombohedra dispersed throughout the matrix, and as zoned (in blue-violet fluorescence microscopy) euhedral rhombohedra, many of which are concentrated in the stylolites.

Two microprobe transects were made, one in an unzoned dolomite rhombohedron (Table 1) and one in a zoned rhombohedron (Table 2). The unzoned rhombohedra commonly contain irregular patches that show greater fluorescence and contain less $\mathrm{Mg}$.

\section{Sample 144-878A-75R-1, 126-130 cm (694.7 mbsf)}

This sample consists of fine-grained packstone with rather large bioclasts of algae and coral that are poorly preserved. Much of the material has neomorphosed to euhedral rhombic crystals up to 0.1 $\mathrm{mm}$ in diameter. A microprobe transect of a euhedral crystal that was nonfluorescent under blue-violet light showed a uniformly low $\mathrm{Mg}$ content and some variation in trace elements. This particular crystal was interpreted, from its petrographic characteristics, to be dolomite before the microprobe analyses. Hence, the analyses were conducted using the operating conditions for dolomite. Two of the analyses resulted in distinct spikes in concentrations of $\mathrm{Mg}, \mathrm{Na}, \mathrm{S}$, and $\mathrm{Sr}$ (Table 3). 
Table 1. Microprobe transect across an unzoned dolomite rhombohedron in Sample 144-878A-75R-1, 32-37 cm.

\begin{tabular}{rrrrrrrr}
\hline Point & Ca & Mg & Fe & Na & Mn & S & Sr \\
\hline 1 & 22.13 & 1.29 & 145 & 83 & BD & 333 & BD \\
2 & 22.20 & 13.97 & 71 & 313 & BD & 401 & BD \\
3 & 24.39 & 14.70 & 143 & 154 & BD & 364 & BD \\
4 & 23.66 & 15.58 & 71 & 151 & BD & 152 & BD \\
5 & 25.12 & 11.73 & 83 & 138 & BD & 317 & BD \\
6 & 25.14 & 11.71 & BD & 114 & BD & 405 & BD \\
7 & 24.77 & 11.60 & 95 & 137 & BD & 356 & BD \\
8 & 25.27 & 11.59 & BD & 161 & BD & 233 & BD \\
9 & 25.50 & 11.73 & BD & 115 & 74 & 270 & BD \\
10 & 25.22 & 11.50 & BD & BD & BD & 245 & BD \\
11 & 24.96 & 11.27 & BD & 184 & BD & 245 & BD \\
12 & 25.63 & 11.21 & BD & 162 & BD & 244 & BD \\
13 & 25.32 & 11.31 & BD & 184 & BD & 281 & BD \\
14 & 25.06 & 11.50 & 71 & 252 & 74 & 307 & BD \\
15 & 25.01 & 11.49 & 107 & 229 & BD & 306 & BD \\
16 & 25.68 & 11.55 & 72 & 207 & BD & 318 & BD \\
17 & 26.84 & 10.24 & 251 & 213 & BD & 349 & BD \\
18 & 25.60 & 11.18 & BD & 230 & BD & 354 & BD \\
19 & 29.98 & 6.91 & BD & 202 & BD & 346 & BD \\
20 & 25.02 & 8.34 & BD & 286 & BD & 371 & BD \\
21 & 24.82 & 13.65 & BD & 242 & BD & 401 & BD \\
MP & 24.89 & 12.31 & BD & 205 & BD & 308 & BD \\
\hline
\end{tabular}

Notes: Values for $\mathrm{Ca}$ and $\mathrm{Mg}$ are reported as weight percent (wt\%); other elements as parts per million (ppm). Point "MP" refers to an isolated analysis in the center of the crystal. $\mathrm{BD}=$ below detection limit.

\section{Sample 144-878A-71R-1, 119-123 cm (656.1 mbsf)}

This sample consists of coarse grainstone to rudstone of bioclasts of mollusks, echinoderms, and algae. Primary pore space is generally occluded with bladed fringing spar, followed by a pore-filling blocky cement with banded fluorescence. The results of a short microprobe transect into a late-stage cement crystal that varies from dull fluorescence to no fluorescence is shown in Table 4.

\section{Sample 144-878A-73R-1, 14-19 cm (674.3 mbsf)}

This sample consists of coarse grainstone to rudstone of bioclasts of primarily fragmented mollusks and algae. Abundant primary pore space is occluded with several generations of cements, which include fringing, inclusion-rich bladed spar, as well as clear, fine-grained equant spar, and coarse, clear, void-filling blocky spar. Results of a microprobe transect through several generations of cements, across an entire pore, are listed in Table 5.

\section{DISCUSSION}

The first three transects have similarities in trace element composition: they show little $\mathrm{Fe}, \mathrm{Mn}$, or $\mathrm{Sr}$ throughout. $\mathrm{Mg}$-poor areas in unzoned dolomite rhombohedra may be representative of partial dolomitization. The third transect (Sample 144-878A-75R-1, 126$130 \mathrm{~cm}$ ) was in a crystal that had similar petrographic characteristics as dolomite (euhedral, little fluorescence). Results from this sample show distinct spikes in the concentration of $\mathrm{Mg}, \mathrm{Na}, \mathrm{S}$, and $\mathrm{Sr}$; this suggests the presence of sulfate mineral microinclusions. Daniel and Haggerty (1988) also noted distinct spikes in the trace element concentrations, especially S, in Upper Jurassic/Lower Cretaceous dolomites from the Galicia margin. Haggerty and Smith (1988) subjected these dolomites to mineral pyrolysis and showed that the microinclusions were sulfate minerals.

The fourth sample (144-878A-71R-1, 119-123 cm) shows much lower levels of $\mathrm{Na}$ and a relatively higher and more consistent concentration of $\mathrm{Fe}$, which might be related to a fresh-water burial influence. More data, including stable isotopic analyses, will be needed to substantiate this possibility.

The last sample (144-878A-73R-1, 14-19 cm) has a quite different trace-element composition. The $\mathrm{Sr}$ concentration is consistently higher. There is a general decrease in $\mathrm{Sr}$ content toward the center (dull fluorescence), whereas the Fe concentration is highest in the fluorescent tips of the bladed fringing spar cement.

Any of the above interpretations are very preliminary and further work will be needed before more conclusive statements about the diagenetic history of the materials can be made.

\section{REFERENCES}

Daniel, M.M., and Haggerty, J.A., 1988. Diagenesis of the Upper JurassicLower Cretaceous carbonate platform of the Galicia Margin at Ocean Drilling Program Site 639. In Boillot, G., Winterer, E.L., et al., Proc. ODP, Sci. Results, 103: College Station, TX (Ocean Drilling Program), 155-169.

Haggerty, J.A., and Smith, M.P., 1988. Characterization of diagenetic fluids of the Upper Jurassic-Lower Cretaceous carbonate platform of the Galicia Margin at Ocean Drilling Program Site 639: evidence for dolomitization by hypersaline brines. In Boillot, G., Winterer, E.L., et al., Proc. ODP, Sci. Results, 103: College Station, TX (Ocean Drilling Program), 145-153.

Shipboard Scientific Party, 1993. Site 878. In Premoli Silva, I., Haggerty, J., Rack, F., et al., Proc. ODP, Init. Repts., 144: College Station, TX (Ocean Drilling Program), 331-412.

Smith, M.P., 1986. Silver coating inhibits electron beam damage of carbonates. J. Sediment. Petrol., 56:560-561.

van Gijzel, P., 1979. Manual of the Techniques and Some Geological Applications of Fluorescence Microscopy: Dallas, TX (Am. Assoc. Stratigr Palynol.).

van Waasbergen, R.J., and Winterer, E.L., 1993. Summit geomorphology of western Pacific guyots. In Pringle, M.S., Sager, W.W., Sliter, W.V., and Stein, S. (Eds.), The Mesozoic Pacific: Geology, Tectonics, and Volcanism. Geophys. Monogr., Am. Geophys. Union, 77:335-366.

"Abbreviations for names of organizations and publications in ODP reference lists follow the style given in Chemical Abstracts Service Source Index (published by American Chemical Society).

Date of initial receipt: 1 February 1994

Date of acceptance: 28 July 1994

Ms 144SR-049 
Table 2. Microprobe transect across a zoned dolomite rhombohedron in Sample 144-878A-75R-1, 32-37 cm.

\begin{tabular}{|c|c|c|c|c|c|c|c|}
\hline Point & $\mathrm{Ca}$ & $\mathrm{Mg}$ & $\mathrm{Fe}$ & $\mathrm{Na}$ & $\mathrm{Mn}$ & $\mathrm{S}$ & $\mathrm{Sr}$ \\
\hline 1 & 23.97 & 12.13 & 262 & 183 & BD & 295 & BD \\
\hline 2 & 24.76 & 11.46 & BD & 185 & BD & 244 & $\mathrm{BD}$ \\
\hline 3 & 24.78 & 11.43 & 72 & 231 & BD & 281 & BD \\
\hline 4 & 24.63 & 11.53 & 72 & 230 & BD & 245 & BD \\
\hline 5 & 24.56 & 11.47 & BD & 253 & BD & 318 & BD \\
\hline 6 & 24.48 & 11.57 & 143 & 207 & BD & 330 & BD \\
\hline 7 & 24.56 & 11.48 & BD & 138 & BD & 110 & $B D$ \\
\hline 8 & 24.66 & 11.63 & BD & 115 & 99 & 257 & BD \\
\hline 9 & 24.39 & 11.64 & BD & 115 & BD & 208 & BD \\
\hline 10 & 24.39 & 11.60 & BD & 92 & BD & 306 & BD \\
\hline 11 & 23.66 & 12.03 & 322 & 136 & BD & 210 & $B D$ \\
\hline 12 & 24.91 & 11.50 & 72 & 116 & $\mathrm{BD}$ & 171 & $\mathrm{BD}$ \\
\hline 13 & 24.80 & 11.59 & 143 & 161 & BD & 208 & $\mathrm{BD}$ \\
\hline 14 & 24.61 & 11.47 & $\mathrm{BD}$ & 115 & BD & 269 & BD \\
\hline 15 & 24.67 & 11.63 & 72 & 46 & BD & 171 & BD \\
\hline 16 & 25.04 & 11.55 & 119 & 92 & BD & 85 & $\mathrm{BD}$ \\
\hline 17 & 24.68 & 11.48 & 95 & 69 & BD & 232 & $\mathrm{BD}$ \\
\hline 18 & 24.93 & 11.30 & 72 & 162 & BD & 256 & $\mathrm{BD}$ \\
\hline 19 & 24.93 & 11.23 & 107 & 162 & BD & 317 & BD \\
\hline 20 & 25.38 & 11.06 & 83 & 140 & BD & 279 & BD \\
\hline 21 & 24.91 & 11.10 & 72 & 162 & BD & 414 & BD \\
\hline
\end{tabular}

Notes: Values for $\mathrm{Ca}$ and $\mathrm{Mg}$ are reported as weight percent (wt \%); other elements as parts per million (ppm). BD = below detection limit.

Table 3. Microprobe transect across a euhedral calcite crystal from Sample 144-878A-75R-1, 126-130 cm.

\begin{tabular}{ccccrcrc} 
Point & Ca & Mg & Fe & Na & Mn & S & Sr \\
\hline 1 & 40.64 & 0.16 & BD & BD & BD & BD & BD \\
2 & 40.56 & 0.37 & BD & BD & BD & 253 & BD \\
3 & 40.65 & 0.19 & BD & 57 & 89 & 284 & BD \\
4 & 39.30 & 0.67 & BD & 1201 & BD & 3841 & 575 \\
5 & 40.13 & 0.22 & BD & 141 & 76 & 399 & BD \\
6 & 40.16 & 0.23 & BD & 85 & BD & 242 & BD \\
7 & 40.89 & 0.25 & 84 & 85 & BD & 431 & BD \\
8 & 41.20 & 0.29 & 145 & 57 & BD & 537 & BD \\
9 & 40.54 & 0.26 & 97 & 141 & BD & 599 & BD \\
10 & 43.30 & 0.32 & BD & 198 & 76 & 705 & 162 \\
11 & 40.40 & 0.35 & BD & 85 & BD & 263 & BD \\
12 & 40.14 & 0.07 & 145 & BD & 139 & 178 & BD \\
\hline
\end{tabular}

Notes: Values for $\mathrm{Ca}$ and $\mathrm{Mg}$ are reported as weight percent (wt\%); other elements as parts per million (ppm). Note the high trace element values in Points 4 and 10 , which are interpreted to contain microinclusions of sulfate, $\mathrm{BD}=$ below detection limit.

Table 4. Microprobe transect in a late-stage calcite cement in Sample 144-878A-71R-1, 119-123 cm.

\begin{tabular}{cccccccc}
\hline Point & $\mathrm{Ca}$ & $\mathrm{Mg}$ & $\mathrm{Fe}$ & $\mathrm{Na}$ & $\mathrm{Mn}$ & $\mathrm{S}$ & $\mathrm{Sr}$ \\
\hline 1 & 38.99 & 0.33 & 169 & BD & 177 & BD & BD \\
2 & 39.48 & 0.20 & 133 & BD & BD & 116 & BD \\
3 & 39.74 & 0.14 & 133 & 85 & BD & 210 & BD \\
4 & 39.56 & 0.14 & BD & BD & BD & 168 & BD \\
5 & 40.32 & 0.16 & 157 & 28 & BD & BD & BD \\
\hline
\end{tabular}

Notes: Values for $\mathrm{Ca}$ and $\mathrm{Mg}$ are reported as weight percent (wt\%); other elements as parts per million (ppm). BD = below detection limit.

Table 5. Microprobe transect across calcite pore-filling cement from Sample 144-878A-73R-1, 14-19 cm.

\begin{tabular}{cccccccc}
\hline Point & $\mathrm{Ca}$ & $\mathrm{Mg}$ & $\mathrm{Fe}$ & $\mathrm{Na}$ & $\mathrm{Mn}$ & $\mathrm{S}$ & $\mathrm{Sr}$ \\
\hline 1 & 42.15 & 0.33 & 96 & 141 & $\mathrm{BD}$ & 369 & 410 \\
2 & 41.88 & 0.31 & $\mathrm{BD}$ & 170 & $\mathrm{BD}$ & 221 & 311 \\
3 & 41.63 & 0.34 & $\mathrm{BD}$ & $\mathrm{BD}$ & $\mathrm{BD}$ & 548 & 224 \\
4 & 42.84 & 0.22 & $\mathrm{BD}$ & 56 & $\mathrm{BD}$ & 116 & $\mathrm{BD}$ \\
5 & 41.84 & 0.55 & $\mathrm{BD}$ & $\mathrm{BD}$ & $\mathrm{BD}$ & 316 & 348 \\
6 & 42.76 & 0.40 & $\mathrm{BD}$ & $\mathrm{BD}$ & 89 & 147 & 249 \\
7 & 42.54 & 0.22 & $\mathrm{BD}$ & $\mathrm{BD}$ & 89 & 158 & $\mathrm{BD}$ \\
8 & 42.28 & 0.33 & 229 & $\mathrm{BD}$ & $\mathrm{BD}$ & 242 & 162 \\
9 & 42.03 & 0.26 & 109 & $\mathrm{BD}$ & 139 & 126 & 149 \\
10 & 41.98 & 0.42 & $\mathrm{BD}$ & $\mathrm{BD}$ & $\mathrm{BD}$ & 158 & 124 \\
11 & 42.23 & 0.21 & $\mathrm{BD}$ & $\mathrm{BD}$ & $\mathrm{BD}$ & 147 & $\mathrm{BD}$ \\
12 & 43.16 & 0.32 & $\mathrm{BD}$ & 141 & $\mathrm{BD}$ & 337 & $\mathrm{BD}$ \\
13 & 43.03 & 0.16 & 133 & $\mathrm{BD}$ & 89 & 211 & 186 \\
14 & 40.35 & 0.28 & $\mathrm{BD}$ & $\mathrm{BD}$ & $\mathrm{BD}$ & 147 & $\mathrm{BD}$ \\
15 & 41.53 & 0.32 & $\mathrm{BD}$ & 85 & 127 & $\mathrm{BD}$ & $\mathrm{BD}$ \\
16 & 42.52 & 0.24 & 217 & $\mathrm{BD}$ & $\mathrm{BD}$ & 168 & 721 \\
17 & 41.79 & 0.58 & $\mathrm{BD}$ & $\mathrm{BD}$ & $\mathrm{BD}$ & 579 & 373 \\
18 & 41.13 & 0.47 & $\mathrm{BD}$ & 56 & $\mathrm{BD}$ & 642 & 820 \\
19 & 42.79 & 0.28 & 133 & 113 & $\mathrm{BD}$ & $\mathrm{BD}$ & 174 \\
20 & 42.65 & 0.26 & 265 & $\mathrm{BD}$ & 76 & 242 & 99 \\
21 & 43.22 & 0.48 & $\mathrm{BD}$ & 85 & $\mathrm{BD}$ & 274 & 709 \\
22 & 42.24 & 0.23 & $\mathrm{BD}$ & $\mathrm{BD}$ & $\mathrm{BD}$ & 158 & 87 \\
\end{tabular}

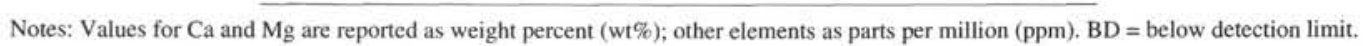

